\title{
GRAMMATICAL ERRORS MADE BY THE TENTH GRADE STUDENTS OF SMK GRAFIKA BINA MEDIA MEDAN IN WRITING ADVERTISEMENT TEXT
}

\author{
Angeline Elisabeth Samosir, Viator Lumban Raja, Fiber Yun A Ginting \\ Catholic University of Saint Thomas \\ Email : viator_lumbanraja@ust.ac.id
}

\begin{abstract}
This research is an attempt to find out the types of errors made by the tenth grade students of SMK Grafika Bina Media Medan based on linguistic category, morphology and syntax and the dominant errors in each category. The population of this research is the tenth grade students amounting 56 students of three classes. As many as 30 students are taken as a sample which is randomly taken 10 students from each class. The research employed the descriptive qualitative research analysis. Based on the result of the analysis, there are 117 errors found in the students' writing advertisement text. In the morphological area, there are errors in article, possessive case, third person singular and comparative so there are 35,90\% errors. Meanwhile, in syntax area the writer found noun phrase, verb phrase, noun and verb construction, word order and some transformation, there are $64,10 \%$. in conclusion, the dominant errors made by the tenth grade students of SMK Grafika Bina Media Medan is syntax errors namedly noun phrase.
\end{abstract}

Key words: Errors, advertisement text

\section{INTRODUCTION}

English is one of the compulsory subjects in Indonesia. Therefore, English has been taught in Indonesia since elementary school. Even though it has been taught since elementary school but as foreign language learners, Indonesians still make mistakes and errors in their English learning process. It is normal for anyone who learns the second language which is different from his mother tongue to make errors. However, it should be distinguished between error and mistake. Error is a deviation of grammar because of different grammatical rules between the two languages. Thus, a native speaker will never make error, but mistake which is a kind of slipof the tongue. Example :

1) Do you have a problem with mouses?

2) You eated too much yesterday?

The two sentences above show errors which cover the form of plurality and past tense. The students think that the form of plurality is suffix $\{-s\}$ added to the root like boots, tables, etc. Also the past tense is marked with $\{-\mathrm{ed}\}$ for regular verb, but not at all verbs are regular. In this case, the students generalize the form of plurality and past tense. 3) You no like caffeine? This is also an error which is caused by interference of his mother tongue. 4) He brang (instead of brought) a book. This is a mistake made by a native speaker and it belongs to slip of the tongue. But sometimes error and mistake are overlapping .

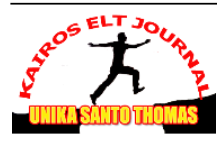




\section{KAIROS ELT JOURNAL, Vol. 2 Agustus 2020 \\ Copyright@2020, ISSN: 2580-4278}

Among the language skills, writing is one of the skills for all language learners with which a student tries to write his feeling, experience and ideas into a sentence and even into a paragraph. It needs hard thinking to produce good writing. Glicken (2008:2) states that good writing requires practice and revision. But a lot of students think that to master the writing skills, they just have to practice without revision. In fact, practice without revision is nothing so that their writing skills never improve. Here is the teacher who has an important part in improving the students' writing skills. The teacher should teach the students how to use the correct grammar properly in sentences which are later organized into a paragraph by using the appropiate writing devices.

When we are good at writing, we can apply its advantages in the advertisement text. Besides, the student can develop their writing skill, and can develop their entrepreneurship skill which can produce money. In wiriting advertisement text the student needs the ability to delivering the correct meaning to the reader but in interesting way.

Such as this research concerning errors in writing advertisement text was once conducted by Mutaoi (2017) entitled Grammatical Error Analysis on Students' Writing in Advertisement Text. Mutaoi found out that the students made errors in verb, adjective and simple sentence. Errors concerning verbs amounts to 11 errors or $28,2 \%$, adjective with 18 errors or $46,1 \%$ and simple sentence only 1 error or $2,5 \%$.

The writer feels interested in conducting the same research to the students of SMK Grafika Bina Media Medan. From the interview with Mr. Mahulae as the English teacher of tenth grade students, he said the student are still poor in English. He confused why the students still make errors although he has taught them well. In regards to this, the writer tried to conduct a research to find out what errors they make when writing advertisement text in order to improve their writing skills. It will be beneficial both to the students and the teacher to know kinds of error they make. With this, the teacher can improve his teaching design based on the findings of the research.

Based on the problem, the writer is interested in conducting a study entitled "Grammatical Errors Made by The Tenth Grade Students of SMK Grafika Bina Media Medan in Writing Advertisement Text." This study is conducted in order to know the types of errors and the dominant errors made by the students in writing advertisement text.

\section{REVIEW OF LITERATURE \\ Error Analysis}

In learning and using a foreign language, one of the most inhibiting factors is the fear of making mistakes or errors. As we know that in language learning process, it is impossible that learners never make any errors when they write or speak because basically learning a target language (English) is different from learning mother tongue. Therefore the students often make errors during the teaching learning process.

To cope with this problem, one of the strategies widely used by linguist are error analysis. Brown (2007:226) says that error analysis is the study of students' error which can be observed, analyzed, and classified to reveal something of the

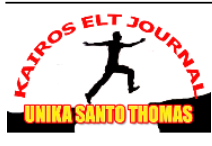




\section{KAIROS ELT JOURNAL, Vol. 2 Agustus 2020 \\ Copyright@2020, ISSN: 2580-4278}

system operating within the learners. Brown's point of view implies that error analysis is useful for the teacher.

With an error analysis, teachers will find out some problems confronting the students. As the name suggest, it is a type of linguistic analysis that focuses on the errors learners make (Gass and Selinker, 2001:78). It is an advantage that students' errors may be found out. The teacher will also gain information concerning learner's difficulties at different levels. Such information is important for the planning of courses and the constructions of the teaching materials. The errors that students make are even potentially important for the understanding of language and it is as a part of the learning process.

In addition, it is necessary to discuss error analysis for teaching English as a foreign language. English teachers should know error analysis because it becomes a useful key to understanding the process of foreign language acquisition. They should know how the target language is learnt or acquired and what the best strategy the learners employ in order to master the target language. By conducting a systematic study of error, they may improve their teaching method and attempt to find some answers or solutions to solve some problems faced by their students.

From the definition above, it can be concluded that error analysis is a way for investigating learners' competence in acquiring a second language acquisition or a foreign language.

\section{The Function of Error}

Peng and Wallace (1999:22) said that the use of error analysis allows for early error detection and correction. As we know that there are many studies on error analysis because error analysis helps to improve the teaching and learning process. If learners' errors and the causes of those errors are identified, errors can be corrected, though not all. Moreover, error analysis helps direct the focus of the teaching and learning process and also can be an evaluation for the teacher about students' progress in their language learning. Dulay et al (1982:138) said that studying learners' error serve two major purposes: (1) it provides data from which inferences about the nature of the language learning process can be made; and (2) It indicates to teacher and curriculum developers which part of the target language students have most difficulty producing correctly and which error types detract most from a learner's ability to communicate effectively. Therefore error analysis not only important to the students' improvement in learning but also for the teachers to evaluate themself. Thus, errors are no longer seen as "unwanted forms," but as evidence of learners' active contribution to second language acquisition.

\section{The Sources of Error}

The four main sources of errors in the learning of a new language are interlingual and intralingual errors (Brown, 2007).

\section{Interlingual Transfer}

Interlingual transfer is a strategy that used by the beginner of learning a second language with combination or interference of mother tongue and second language. It means that the student try to mix their language when they practice English as their second language. Learners will make errors as the result of transfer from the native language since they have not been familiar with the second language

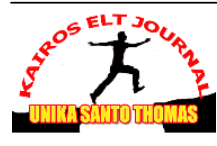




\section{KAIROS ELT JOURNAL, Vol. 2 Agustus 2020 \\ Copyright@2020, ISSN: 2580-4278}

system (negative influence of the mother tongue).e.g. "My father a doctor", students do not know the system of the sentence and translate it directly, so it seems like their mother tongue and the effect of this, beginner will feel difficult to organize their language in writing.

2. Intralingual Transfer

Intralingual transfer is the major factor in second language learning within the target language itself. This error is made by the student who have begun to acquire parts of target language but still lack of competence and felt confused with the structural of second language because of the target language that the student studied was different from their mother tongue.

\section{Context of Learning}

Context of learning is major source that overlaps both types of transfer, in the case of school learning or the social situation in the case of untutored second language learning. Students make errors because of misleading explanation provided by the teacher, faulty presentation in a textbook or a memorized pattern that is not contextualized. Example: "Good evening" (leave taking) The students should say "Good night" to end the meeting or the conversation in the evening time. 4. Communication Strategies

Communication strategies were defined and related to learning styles. Learners obviously use production strategies in order to enhance getting their message across. However, at times these technique can becomes a source of error by themselves. Example: 1. A: "How are you ?" B: "I'm fine, thank you." 2. A: "What is my name ?" B: "I am Peter" (actually B should say "I don't know. You tell me because he doesn't know) It means that they have already fixed it in their mind, so sometimes when the qestion in changed into, "what are you ?" they still answer the same, "I am fine, thank you." This is what is meant by communication strategies.

\section{The Classification of Errors}

Dulay et al. (1982:146) points out four basic classification in errors, there are classification based on linguistic category, surface strategy, comparative analysis and communicative effect. In this research, the writer focused on linguistic category.

\section{The Classification of Errors Based on Linguistic Category}

Dulay et al. Further said these Linguistic category taxonomies classify errors according to either or both the language component or the particular linguistic constituent the errors affects. Language components include phonology (pronounciation), syntax and morphology (grammar), semantics and lexicon (meaning and vocabulary), and discourse (style). In case of writing analysis, it is focused on morphology and syntax and those types of errors are :

1. Morphology

a. Indefinite article incorrect, Example: A apple, instead of An apple.

b. Possessive case incorect,

Example: that is Martin house, instead of that is Martin's house.

c. Third person singular verb incorrect, 
Example: Jimin take his clothes, instead of jimin takes his clothes.

d. Simple past tense incorrect,

Example: Silvia drinked coffee and watch tv last night, instead of Silvia drank cofee and watched tv last night.

e. Past participle incorrect,

Example: I had play soccer, instead of I had played soccer.

f. Comparative adjective/adverb incorrect,

Example: He got up more higher, instead of He got up highier.

2. Syntax

a. Noun phrase

1. Determiners

Example: the little boy hurt its leg instead of the little boy hurt his leg

2. Nominalization

Example: by to cook it, instead of by to cooking it.

3. Number

Example: he got some leaf, instead of he got some leaves.

4. Use of pronouns

Example: I don't know _ in English, instead of I don't know it in English.

5. Use preposition

Example: he writes _ the table, instead of he writes on the table

b. Verb phrase,

1. Omission of verb

Example: $\mathrm{He}_{-}$in the water, instead of $\mathrm{He}$ is in the water

2. Use of progressive tense

Example: He _ going, instead of He is going

3. Agreement of subject and verb

Example: The apples was coming down, instead of the apples were coming down.

c. Verb and verb construction,

Example: I go play, instead of I go to play.

d. Word order,

Example: The bird (object) he was going to shoot it, instead of He was going to shoot the bird.

e. Some transformation,

Example: They won't have no fun, instead of They won't have fun.

\section{Writing}

Writing is one way to communicate with other people besides speaking, reading, and Listening. The word 'writing' seems to be very simple and easy to understand. However, it cannot be ignored. Writing is very important for the students. From writing students can explore their mind. Writing is basic language skill, as important as a speaking, listening, and reading (Harmer,2006:79-80). According to Glicken (2008:1), writing is speaking, with guidelines provided for the reader so that when we read something we know exactly how the writer would present the material if he or she, apart from were speaking it out loud. To make sure that the readers know exactly how the writer would present the material, writing skill needs write not only semantically correct but they should also use correct

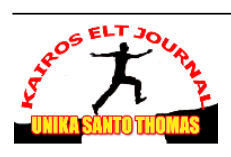




\section{KAIROS ELT JOURNAL, Vol. 2 Agustus 2020 Copyright@2020, ISSN: 2580-4278}

grammar. Therefore, writing needs hard thinking and hard work in order to produc writing. Even though writing skill is difficult, but there is still foreign language learners are able to understand the writing skill. We need to know that to be able to write well, foreign language learners must practice a lot. Tchudi and Yates. (1983:14) said that he more students write, the more likely they are to have developed their imaginations and have more likely they are to choose that openended topic, in essence, inventing their own assignments. Although we are often wrong, but foreign language learners must keep trying in order to produce good quality in writing anduseful for many people.correct grammars, apart from other requirements such as coherence, unity, diction, punctuation, etc.

\section{The Purposes of Writing}

According to May (2011:173), the main purposes of writing can be thought as follows:

1. Conveying information, instuction and directions

2. Expressing feelings

3. Ordering, clarifying, recording and reflecting on ideas, experiences and opinions

4. Giving and gaining aesthetic pleasure

Accroding to Miller (2006:47) the purposes of the writing are :

1. to understand experiences,

2. to report information,

3. to explain information,

4. to evaluate something,

5. to analyze images,

6. to analyze texts,

7. to persuade others,

8. to inspire others,

9. to amuse others, and

10. to experiment with form.

\section{The Process of Writing}

According to Harmer (2004:4-5), steps of writing consisting of four stages (Planning, Drafting, Editing, and Final Draft). These steps are able to help the students to write well. The four steps of writing are:

1. Planning In planning, there must be three considerations in this stage. The first is thinking the purpose of writing. It will influence other features, like text type, language use, and information or content of the text. The second is related to the readers. it will influence, whether will use formal or informal language. The last consideration is the content structure. It is about the sequence of the text. In this consideration, the writer know how to sequence facts, ideas, and arguments in the best way.

2. Drafting The second step is drafting. After finishing their plan, students are led to step on the second stage which is drafting. In this stage, students are starting to write their ideas or topics they have selected before. They can also make outline about their writing content before they start to write in the best form. 


\section{KAIROS ELT JOURNAL, Vol. 2 Agustus 2020 \\ Copyright@2020, ISSN: 2580-4278}

3. Editing In this stage, the students are checking the drafts that they have been written by themself. After they are checked and edited, students will start to write in the best form of writing based on their own text type.

4. Final Draft This is the fourth or the last stage of the writing this process. This is a finished product and considered the best writing after going through the examination and editing. At this stage, the author is permitted to publish their writing to the reader.

\section{Advertisement Text}

Advertisement is quite common in our modern society. We can find it in a newspaper, television, or internet advertising. Commonly, the advertisement contains about selling products and services. In business, advertisement is a form of marketing communication used to encourage, persuade an audience (viewers, readers, or listeners; sometime a specific group) to buy or use company services. While Cambridge advanced learner's dictionary (2008:21) said that advertisement is a picture, short film, song, etc. which tries to persuade people to buy a product or service. The definitions above has one similarities where advertisement is the way to sell the product or service. The objective of an advertisement is to induce customer in buying a product (Dhillon, 2008:59). Therefore the advertisementis made as good as possible to attract the attention of the reader. But the objectives above is the objective of advertisement in general which is different from perfect advertisement. The objective of a perfect advertisement is to help consumer in buying more smartly (Yilaz,2017:81).At this point advertisement helps the consumer in determning or selecting the product. Therefore advertisement not only benefits the seller but also the reader. The researcher can conclude that an advertisement is not only a picture, short film and ect, but also text type. Which tries to persuade people to buy a product or service more smartly. Advertisement have categories. According to Kurtz et al (2009:503), advertisements fall into two broad categories (Product advertisement and Institutional Advertisement). In this research, the writer focused on product advertisement especially promote services as follows:

1. Product Advertising Product advertising is designed mainly to promote goods and services. Product of goods are car, TV, cell phone,book, shoes, bag, motorcycle, bicyle etc. In advertisement, product of goods usually show what the things are to the audience and make them interest and want to buy it. Product of services are computer service, tailor, cleaning service etc. In product of service advertisement usually offer service to the audience and make them interest and want to use the service.

2. Institusional Advertising In contras, promote a concept, an idea, a philosophy or the goodwil of an industri, company, organization, person, geographic location or government agency.

\section{RESEARCH METHOD}

In conducting research, the writer made a research design. According to Kumar (2011:93) research design is a procedural plan that is adopted by the writer to answer questions validly, objectively, accurately and economically. Through a research design you decide for yourself and communicate to others your decisions

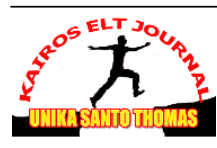


regarding what study design you propose to use how you are going to collect information from your respondents. This research used qualitative descriptive research method to analyze the students' error and to know the types of the grammatical errors dominantly made by the students. Qualitative research is specially important in the behavioural sciences where the aim is to discover the underlying motivates of human being (Kothari,2004:30).

\section{DATA ANALYSIS}

\section{The Description of Data}

This research was conducted at SMK Grafika Bina Media Medan by online with 30 participants. The data collected in this research were the students' writing about advertisement that has provided.

\section{The Result of The Students' Writing}

After collecting the data, the errors were analyzed based on procedures explained in Chapter III. After collecting the data, the errors were counted by using table and calculated the number of each error.

Table 1. The Recapitulation of Student's Error

\begin{tabular}{|c|l|c|c|c|}
\hline No & \multicolumn{1}{|c|}{ Name } & M & S & Total \\
\hline 1 & Adler Manurung & 2 & 5 & 7 \\
\hline 2 & Agnes Jessica Ginting & 5 & 0 & 5 \\
\hline 3 & Amerosius DM Purba & 0 & 3 & 3 \\
\hline 4 & Andre Alvonso V Hasugian & 1 & 1 & 2 \\
\hline 5 & Arwan Sinurat & 0 & 3 & 3 \\
\hline 6 & Ebril Sitanggang & 0 & 2 & 2 \\
\hline 7 & Egia Putra Ibrema Sembiring & 4 & 1 & 5 \\
\hline 8 & Firman NO Siahaan & 3 & 1 & 4 \\
\hline 9 & Josephin Ginting & 1 & 4 & 5 \\
\hline 10 & Hiskia Tarigan & 0 & 3 & 3 \\
\hline 11 & Irvan Pernando Nainggolan & 2 & 3 & 5 \\
\hline 12 & Indira Eunike Veminta & 0 & 3 & 3 \\
\hline 13 & Kristiani Laia & 1 & 1 & 2 \\
\hline 14 & Lois Angelo Perangin-angin & 0 & 1 & 1 \\
\hline 15 & Meisita & 4 & 2 & 6 \\
\hline 16 & Nissi sari sitanggang & 1 & 2 & 3 \\
\hline 17 & Nadya Malau & 1 & 0 & 1 \\
\hline 18 & Ray Aditya Bangun & 1 & 4 & 5 \\
\hline 19 & Richard Hutauruk & 3 & 2 & 5 \\
\hline 20 & Ronaldo Situmorang & 1 & 2 & 3 \\
\hline 21 & Sevy Br. Ginting & 1 & 7 & 8 \\
\hline 22 & Sapril Pardamean Tanjung & 0 & 2 & 2 \\
\hline 23 & Tisya Manullang & 2 & 4 & 2 \\
\hline 24 & Tesalonita Bangun & 1 & & 3 \\
\hline
\end{tabular}


KAIROS ELT JOURNAL, Vol. 2 Agustus 2020

Copyright $\odot 2020$, ISSN: 2580-4278

\begin{tabular}{|c|l|c|c|c|}
\hline No & \multicolumn{1}{|c|}{ Name } & M & S & Total \\
\hline 25 & Wira Fernandes Simbolon & 1 & 2 & 3 \\
\hline 26 & Xaverius Simamora & 1 & 1 & 2 \\
\hline 27 & Yulianti Mendrofa & 2 & 1 & 3 \\
\hline 28 & Yesaya Prayuda Sinaga & 2 & 7 & 9 \\
\hline 29 & Yohana Situmeang & 2 & 4 & 6 \\
\hline 30 & Yupen Pakpahan & 0 & 2 & 2 \\
\hline \multicolumn{2}{|c|}{ TOTAL } & 42 & 75 & 117 \\
\hline
\end{tabular}

\section{Errors in Morphology}

The following are the morphological inflectional morphemes: (1) Article (2) Possessive (3) Third person (4) simple past tense (5) past participle (6) comparative. Based on the analysis, the witer found out article incorrect, possessive incorrect, third person incorrect and comparative incorrect with 42 errors concerning morphological forms or 35,90\%. For Example:

1. Do you need a help ? instead of Do you need help ? (Article Incorrect)

2. Bilbo_house instead of Bilbo's house ( Possessive Incorrect)

3. We offers instead of we offer ( Third Person Incorrect)

4. More happy instead of Happier ( ComparativeIncorrect)

\section{Errors in Syntax}

Based on the identification of the writer, there are 75 or $64.10 \%$ errors made by the students. The writer found noun phrase incorrect, verb phrase incorrect, noun and verb construction incorrect, word order incorrect and some transformation on the students' writing advertisement text. For Example:

1. Me and my team instead of $I$ and my team ( Noun phrase incorrect)

2. We _ going to fix it instead of we are going to fix it (Verb phrase incorrect)

3. We are going _ help you instead of we are going to help you (Verb and verb construction incorrect)

4. A week only instead of only a week ( Word order incorrect)

5. Your computer won't have virus anymore instead of your computer won't have virus ( Some transformation incorrect)

Table 2. The Types of Students' Errors

\begin{tabular}{|c|l|c|c|}
\hline \multirow{5}{*}{ Morphology } & Category & Number & Percentage \\
\cline { 2 - 4 } & Defined Article Incorrect & 13 & $11,11 \%$ \\
\cline { 2 - 4 } & Possesive Case Incorrect & 17 & $14,53 \%$ \\
\cline { 2 - 4 } & $\begin{array}{l}\text { Third Person Singular Verb } \\
\text { Incorrect }\end{array}$ & 8 & $6,84 \%$ \\
\cline { 2 - 4 } & Simple Past Tense Incorrect & 0 & $0.00 \%$ \\
\cline { 2 - 4 } & Past Participle Incorrect & 0 & $0.00 \%$ \\
\cline { 2 - 4 } & Comparative Incorrect & 4 & $3,42 \%$ \\
\hline \multirow{2}{*}{ Total } & & $\mathbf{4 2}$ & $\mathbf{3 5 , 9 0 \%}$ \\
\hline & Noun Phrase & 28 & $23,93 \%$ \\
\hline \hline
\end{tabular}


KAIROS ELT JOURNAL, Vol. 2 Agustus 2020

Copyright $\bigcirc 2020$, ISSN: 2580-4278

\begin{tabular}{|c|l|c|c|}
\hline \multirow{3}{*}{ Syntax } & Verb Phrase & 15 & $12,82 \%$ \\
\cline { 2 - 4 } & Verb and verb construction & 9 & $7,69 \%$ \\
\cline { 2 - 4 } & Word Order & 22 & $18,80 \%$ \\
\cline { 2 - 4 } & Some transformation & 1 & $0,85 \%$ \\
\hline Total & $\mathbf{7 5}$ & $\mathbf{6 4 , 1 0 \%}$ \\
\hline \multicolumn{2}{|c|}{ All Total } & $\mathbf{1 1 7}$ & $\mathbf{1 0 0 \%}$ \\
\hline
\end{tabular}

\section{Discussion}

The purpose of writing is to convey information accurately, effectively, and appropriately. Writing product is necessary to be grammatically correct. Teaching and learning process cannot be free from error. Based on the phenomena, there are some problems in students' writing skill, especially in writing composition. Although, the students must take writing subject, in fact there are still many students who have difficulties in writing composition. There are four categories to classify errors. There are linguistic category, surface strategy taxonomy, comparative taxonomy, and communicative effect taxonomy (Dulay,1982:145). In this research, the writer uses linguistic category to classify errors. As shown in linguistic category the error is classified into two categories, morphology and syntax. Morphology errors appear with 42 items of error or $35.90 \%$ consisting of article incorrect with 13 items or $11.11 \%$, possessive case incorrect with 17 items or $14.53 \%$ third person singular verb incorrect with 8 items or $6.84 \%$ comparative incorrect with 4 or $3.42 \%$. The writer found four types of errors in syntax with 75 errors item or $64.10 \%$, noun phrase incorrect with 28 errors item or $23.93 \%$, verb phrase incorrect with 15 errors item or $12.82 \%$, verb and verb construction with 9 errors item or $7.69 \%$, word order incorrect with 22 errors item or $18.80 \%$ and Some transformation incorrect with 1 errors item or $0.85 \%$.

From the data above, syntax errors ranks the highest with 75 or $64.10 \%$ and morphology with 42 or $35.90 \%$. In syntax, noun phrase is in the first position with 28 errors or $23.93 \%$. Word order was in the second position with 22 errors or $18.80 \%$. Verb phrase was in the third position with 15 errors or $12.82 \%$. Verb and verb construction was the fourth position with 9 errors or $7.69 \%$ and in the fifth is some transformation with 1 errors or $0.85 \%$.

In morphology, possesive case incorrect is in the first position with 17 errors or $14.53 \%$. Article incorrect is in the second position with 13 errors or $11.11 \%$. Third person incorrect is in the third position with 8 errors or $6.84 \%$. Comparative incorrectis in the fourth position with 4 errors or $3.42 \%$ and the last positions are simple past tense incorrect, past participle incorrect and past tense incorrect with 0 errors or $0.00 \%$.

\section{CONCLUSION}

Based on the analysis data it can be concluded as follows:

1. From the 30 advertisements, the students made $35.90 \%$ error in morphology. There are $11.11 \%$ percentage of error about article, $14.53 \%$ percentage error about possesive, $6.84 \%$ percentage of error about third person, $3.42 \%$ percentage of error about comparative.

2. The students made $64.10 \%$ error in syntax. There are $23.93 \%$ percentage error about noun phrase, $12.82 \%$ percentage of error about verb phrase, $7.69 \%$

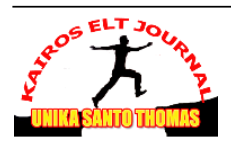


KAIROS ELT JOURNAL, Vol. 2 Agustus 2020

Copyright@2020, ISSN: 2580-4278

percentage of error about verb and verb construction, $18.80 \%$ percentage of error about word order, $0.85 \%$ percentage of error about some transformation.

\section{BIBLIOGRAPHY}

Brown, H. D. 2007. Principles of Language Learning and Teaching ( $5^{\text {th }}$ Ed).New York: Pearson Education.

Cambridge International Dictionary of English. 2008. Cambridge Advanced Learner's Dictionary $\left(3^{\text {rd }} E d\right)$. New York: Cambridge University Press.

Dhillon, J. 2008. Longman Panorama Civis 7. New Delhi: Dorling Kindrsley.

Dulay, H., et.al. 1982. Language Two. New York: Oxford University Press.

Gass, S. M., and Selinker, L. 2001. Second Language Acquisition and Introductory Course $\left(2^{\text {nd }} E d\right)$. New Jersey: Lawrence Erlbaum Associates.

Glicken, M.D. 2008. A Guide to Writing for Human Service Profesionals. New Yok: Rowman \& Littlefield Publisher, Inc.

Harmer, J. 2004. How to Teach Writing. Harlow: Pearson Education. 2006. How to Teach Writing. London: Longman.

Howitt, D., and Cramer, D. 2000. First Step in Research and Statistics: A Practical Workbook for Psychology Students. London: Routledge.

Kothari, C. R. 2004. Research Methodology: Methods and Techniques. New York: SAGE Publising.

Kumar, R. 2011. Research Methodology: A Step-by-Step Guide for Beginner. London: SAGE publication.

Kurtz, D. L., et.al. 2009. Contemporary Marketing. Ontario: Nelson Education.

May, P. 2011. Child Development in Practice: Responsive Technique and Learning from Birth to Five. New York: Routledge.

Miles, M. B., and Huberman, A. M. 1994. Qualitative Data Analysis: Expanded Sourcebook $\left(2^{\text {nd }} E d\right)$

Miller, R. K. 2006. Motives for Writing. New York: Mc Graw-Hill Companies, Inc.

Mutaoi,A.M. 2017. Grammatical Error Analysis on Students' Writing in Advertisement Text. Sarjana's Thesis, Faculty of Education and Teacher 
KAIROS ELT JOURNAL, Vol. 2 Agustus 2020

Copyright $\bigcirc 2020$, ISSN: 2580-4278

Training: The State Islamic University Sultan Maulana Hasanuddin Banten.

Oshima, A., and Hogue, A. 2007. Introduction to Academic Writing ( $3^{\text {rd }}$ Ed). New York: Pearson Education.

Peng, W. W., and Wallace, D. R. 1992. Software Error Analysis. New Jersey: Silicon Press.

Sofer, M. 2006. The Translator's Handbook. Rockville: Schreiber Publishing.

Tchudi, S. N., and Yates, J. 1983. Teaching Writing in the Content Areas: Senior High School. Washington DC: National Education Association.

Westwood, P. S. 2008. What Teachers Need to Know about Reading and Writing Difficulties. Melbourne: ACER Press.

Yilaz, R. 2017. Narrative Advertising Models and Conceptualization in the Digital Age. Harrisburg: IGI Global. 